\title{
Methods for Controlling the Cost of Construction Projects Based on Aggregated Groups of Indicators
}

\author{
Anna Mostovaya \\ Department of Economics and Management in Construction \\ Moscow State University of Civil Engineering \\ Moscow Russian Federation \\ annamg83@mail.ru
}

\author{
Varvara Dikareva \\ Department of Economics and Management in Construction \\ Moscow State University of Civil Engineering \\ Moscow Russian Federation \\ dikareva-va@rambler.ru
}

\begin{abstract}
In modern construction new materials, technologies, types of works are actively introduced. A major role in this is played by international cooperation in business. Planning of construction projects is carried out on the basis of a large number of reference information, standards, regulations and they in turn have to be updated actively. The article discusses the issue of cost and proposes approaches to systemic organization of work. In previous periods, isolated tariffs were subject to updating. In modern conditions it is stated that it is necessary to switch to indicators assessing the set of works, design solutions, certain volumes within the framework of the project, and taking them into account can solve local problems. This idea is not new in itself. But in the article it is proposed to approach the relevant processes through the management of an integrated database. The aggregated indicators of cost are subject to mutual reconciliation between the customer and the contractor, and this allows to allocate the isolated norms and tariffs that are relevant at a given time, which require updating, recalculation or new calculation. At the same time, the integrity of ties within the framework of an integrated database allows to make adjustments at the same time to the catalogue of resources, norms and prices, aggregated indicators of the cost of construction. The study resulted in the formation of the structural features of the relational database of information on single and aggregated indicators of the construction cost. Provided that Russian unit rates and regulations are not an international standard, their development should be carried out in the framework of Russian practice. However, for the development of international relations it is essential to form the aggregated indicators. Such indicators are based on general principles that are understandable to any investor. As a rule, parts of the construction objects or whole objects are considered. In many countries such indicators are uniform and easy to read, since the general classification of the construction projects is almost the same everywhere.
\end{abstract}

Keywords: cost, project management, aggregated indicators, investments, international projects

\section{INTRODUCTION}

Project management involves the selection of the most effective options for their implementation, and at the stage of development of investment idea, materials, works, used machines and mechanisms and other resources are planned on the basis of average isolated natural indicators and prices. In construction practice, without the use of computer-based project management programs, no one currently works, except for micro business, but not always. For engineers, designers the task is to choose different design solutions that best meet the interests of the end user.

Working with software products implies precise algorithms that work on numbers and any free interpretations, representations cannot be applied. There are many foreign programs based both on local and international standards for data exchange. Taking into account the verified digital models specialists who have knowledge of the cost of resources help determine the economic feasibility of a solution. When implementing a project with foreign participation and based on foreign standards, it becomes difficult to apply methods of cost calculation according to Russian rules. There are neither necessary system interface methods, nor any universal data protocols. The very approach to substantiating project options is obvious when optimal economic and technical solutions are sought. But in view of the variety of options emerging and the constant emergence of new solutions, it is difficult to make the necessary calculations quickly. Many foreign solutions continue to emerge in construction practice, including BIMbased technologies. Such systems require even greater consistency between the data used. It becomes necessary for foreign investors and customers to link their own classifiers and directories with Russian information resources and data. Specially organized work and methods of solving problems are particularly necessary. The approach to cost determination through aggregated groups of indicators facilitates the work of both Russian and foreign specialists, as it allows us to exclude immersion in all isolated norms and tariffs and quickly solve issues through aggregated indicators. The ultimate goal of any 
and the funds are over, incomplete construction and virtually dead capital are formed without the possibility of its restoration.

According to the Court of Auditors of Russia, the volume of construction in progress as of the 3rd quarter of 2019 exceeded 5 trillion rubles. [2]. Thus, the problem of project management and cost is extremely urgent. Currently, dozens of facilities are not delivered on time. The deadline is extended for the following year. Contrary to the measures of the relevant agencies, even within one year, as a rule, the facilities are not delivered. The problem concerns about half of the Federal Targeted Investment Program (FTIP). The amount, which today is total for both open and closed sources, is 5.3 trillion rubles, which is related to uncompleted objects. And this is just one of the programs. There are plenty of commercial projects, individual federal and regional procurement projects, etc., that increase the scale of the problem. Everything is based on unreliable estimated cost, which in the future forms the basis of budgets, etc. When signing the contract, the parties make preliminary estimates based on reference data and cost indicators. In the face of inflation, rising wages, price indicators and current resource cost are not updated at proper intervals. When this happens systemically, the problem is exacerbated with acceleration. The actual consequences of such processes have caused the growth of uncompleted construction, which is mentioned by the Court of Auditors of the Russian Federation.

The analysis of scientific literature shows that the scientific community is actively studying problems at the level of determining the estimated cost. In works [4, 7, 14] authors draw attention to the importance of correct selection of prices, which can lead to reasonable reduction of the cost of works. But cost reduction cannot be the main goal. As shown above, this problem on the contrary is now the main one, entailing an increase in uncompleted construction. Therefore, we need the reliability of the price. The author of another study [3] points out that the determination of the amount of resources and cost of the construction object is necessary at each stage of the life cycle of the project implementation and this requires models of management of the development of the information base of the object. In order to develop and implement an object cost management system in construction production, it is necessary not only to define the main levels and parameters of selection when taking into account solutions from organizational and technological documentation, but also to build an application software architecture for the operation of the management system at all subsequent stages of the life cycle of the construction object. In the development of this idea, the author [6] considers the application of two software products "Adept: Construction Management", "Al-Invest. Construction", when substantiating the efficiency of construction of non-residential real estate objects. The article shows how to substantiate the efficiency of the project on the basis of calculated demand, sales price, investing costs.

A rather important question is raised in connection with the possibility of applying aggregated indicators of construction [1]. The methodology of aggregated indicators was implemented during the planned economy. In addition, there were indicators for objects of analogues. In terms of state project and to consider that the system works with a permissible level of error. If the facility is only partially built 
procurement, appropriate approaches are in demand to determine the initial maximum price of the contract. With a wide list of objects included in the directories, there is interest in collections of aggregated indicators and commercial enterprises. As a follow-up to this idea, a valuable approach is proposed to determine the cost of a set of objects or works [5]. The study proposes a methodology for determining the estimated cost of construction on the basis of the cost indicators of functional groups of premises on the example of an object of other purposes. A functional group of premises is a collection of spatially related premises and communication lines designed to perform certain production functions. This technique can be used to estimate the real estate object, to form the estimated cost of the designed objects, to estimate investment projects taking into account the multivariate design. The article also provides an analysis of the effectiveness of using the cost indicators of the functional groups of the premises to calculate the estimated cost of construction in comparison with the results of similar calculations obtained using the indicators of analog objects (an object comparable in terms of functional purpose, technical and economic indicators and design characteristic of the designed construction object) and resource consumption standards. These are standards setting resource consumption in physical terms and standards defined in percentage terms, including standards of general economic and general production expenses, planned profit, transporting expenses.

Thus, there are many approaches to determining the cost of construction in the scientific literature. The issue of implementation of TIM (technology of information modeling) and automation of calculations is raised. At the same time, the analysis of the works shows that the process of determining the objective cost itself requires the management of the stage of creation, clarification, updating of normative or reference elements of the cost of the object [9, 10, 12, 14]. It is the methodological approach of determining the components of the cost of the object at the pre-investment stage and applying them in an updated form to calculate the final cost of the object for the implementation of construction works that becomes demanded in practical conditions.

In foreign literature on the issues of determining the construction cost the regulatory and legal provisions specific to each country are described. The ddifferences from Russian practice are manifested in the approaches to taxation, reporting, the methods of calculating the specific financial and other indicators and standards in accordance with the local laws. Nonetheless, the use of modern information technologies and BIM models reveals the universal principles for determining the cost. Russian researchers brought these issues to light. These were shown above. Foreign researches also approach to the creation of relational database relying primarily on the local and unit prices. At the same time, for the international cooperation the common approach represents the use of aggregated indicators for the construction facilities, the classification of which is approximately the same in all countries.

So, in order to solve this problem, that is to create a single database resulting in aggregated indicators, it is necessary: maintenance of construction resources catalogs. This includes compliance with the application of units of measurement, codification, resource names, pricing and territorial affiliation;

regular comparison of the construction resources specified in the estimate documentation with the catalogue for the appearance of new, not documented, duplicating other similar names;

classification of resources within the framework of implemented projects to identify the main cost-forming and often demanded.

The set of these processes is particularly necessary for large enterprises of the construction industry, where the price of error is high and in principle system transparent management activity is necessary.

In the case of system organization of catalogs, the further purpose is to maintain aggregated groups of works, standards of price of design solutions. The corresponding scaled-up values allow you to quickly estimate planned costs, keep records of actual work performed by contractors, and analyze cost deviations from standards. Thus, the methodology of construction of the data system (catalogs, etc.) is the basis of methods of research of this article. The thesis about the absence of rigid links between data sources (cost documentation), and further between collections and catalogs of resources, works is the main one for finding ways to increase the efficiency of the pricing process in construction.

\section{RESULTS}

The methodical approach of organization of catalogs maintenance and formation of aggregated groups of indicators by types of works at the present stage can be implemented only if it is assumed to form databases of resources and manage them taking into account the construction of rigid links and relations and application of algorithms of construction of aggregated types of works. At present, in science, processing of many types of data to get certain results with new quality is done precisely by means of database construction methods. Databases also allow complex queries to be made to retrieve data from different sources at the same time. If catalogs are maintained systematically, it allows both actual monitoring of resource costs, especially by costgenerating factors, and predictive models of price increases for those resources that are not monitored or that are not regularly monitored. Work on the catalogue is primarily necessary in terms of orderly maintenance of resource names, their codes, units of measure. The set of catalogs of resources, norms, prices for isolated works, as well as aggregated groups of works and design solutions form an isolated database, which should ultimately be the main tool of cost management. The database must meet consistency, minimum redundancy, and integrity conditions. It must also be a relational database that represents an associated collection of database entity tables. The most important advantage of relational databases is that it is possible to store logically grouped data in different tables and define links between them, combining them into an integrated database. This data organization reduces the redundancy of stored data, simplifies the entry and 
organization of queries and reports. At present, the analysis of practice, scientific works, shows that the task is neither fully solved, nor set. The scientific works which consider ways of implementing TIM, are as close as possible to solving these problems. But without the above database, the efficiency of the TIM implementation tends to be zero. When implementing BIM, the database described above should be based on it.

On the basis of the proposed approaches, a system of cost monitoring and cost management should eventually be built. First, it should allow enterprises at the level of investor and customer service to quickly estimate the cost of the planned object at the pre-investment stage with the help of aggregated solutions. Second, carry out cost decomposition in the transition from an investment idea to the development of a specific project. Third, evaluate and monitor the performance of the contractor's work, carry out an analysis of the performance of the work, see through the aggregated groups of deviation indicators and determine general trends. In addition, the cost monitoring system based on the relational database allows to quickly agree on changes in the cost structure within the approved contract cost between the customer and the contractor; to make a choice between resource and basis-index method taking into account maximization of accuracy and completeness of calculations. Such a system also allows for a risk-oriented approach, as changes in pricing approaches, or changes in cost itself by activity type, are tracked quickly. As it is known, construction is an extremely risky activity and a lot of works $[8,11,13,15]$ are devoted to risk management.

\section{DISCUSSION}

The proposed system of cost management, including cost control and risk-oriented approach implementation, is based on the concept of formation of aggregated groups of indicators, which allow to quickly monitor changes and determine inaccuracies in the estimated rationalization. A separate task, which causes the achievement of the desired result, is directly classification, grouping, aggregation of works, the set of which represents a particular object of construction. These actions are necessary to group cost indicators and create standards for the cost of works, design solutions, etc. The local estimate documents themselves do not allow such work to be carried out.

You must apply project management methods, work scheduling principles, and work allocation. The time-specific steps of individual work quantities are to be evaluated. After that, aggregated indicators of construction cost for types of works or other aggregated meters are formed. Thus, the project management methodology should become an important part of construction cost management methods. Evaluation of types of works, their groups, design solutions makes it possible to determine shortcomings in methodological and reference documents on pricing in construction and to make changes to existing documents GESN, FER, catalogs of construction resources, methods, etc.

At present, there are collections of aggregated indicators of the cost of construction facilities operating at the state level. But the lack of strong linkages across the cost chain from resource catalogs to single prices and beyond to strengthened prices prevents the entire system from developing cost standards dynamically. It is necessary to have reliable sources of primary documentation - first of all in the form of local estimates on construction. If such a task is faced by a commercial enterprise, the project office or other departments responsible for the implementation of the project need to analyze all estimated documentation, collect and process all indicators. For businesses, because of the relatively small scale of work, the collection and collation of data on resources and their cost can be labor-intensive and very time-consuming. There are units of large corporations that can do this. State bodies have significantly different opportunities. A lot of documents pass through the bodies of expertise, which have the required information. The organization of data collection from the estimated documentation and their subsequent processing to ensure the relevance of resource catalogs, etc., is an effective solution.

\section{CONCLUSION}

Control of the cost of construction remains a pressing issue. There is a great need for foreign investment in the country. For foreign investors and technical customers, costing tools optimized for use in software products are highly sought after. The approaches proposed in the article show how to solve such problems. As for the Russian market and participants, the scale of the problem being solved is also large. A large number of constructions in progress remain. For projects planned to be financed from the state budget, very often contracts are simply not concluded because of their impracticability. Potential performers see that the price of the contract being bid is below the maximum permissible, or they simply cannot determine it. Therefore, the implementation of value management methods, which allow determining the reliable value at the level of enlarged indicators, and on this basis to adjust unit prices, and further present an objective price for contracts for construction works is really in demand. Scientific research in this field is a new direction of research of investment and construction projects and a factor of their successful implementation.

\section{REFERENCES}

[1] M. V. Balashova, "Ostryakova YU.E. Ukrupnennye pokazateli smetnoj stoimosti ob"ektov kapital'nogo stroitel'stvan", Molodyeuchenye razvitiyu Nacional'noj tekhnologicheskoj iniciativy (POISK), 2019, no. 1-1, pp. 266-268 (in Russian).

[2] A. L. Kudrin, "Ob"em nezavershennogo stroitel'stva v Rossii prevyshaet 5 trln rublej", Informacionnoe telegrafnoe agentstvo Rossii (ITARTASS) [Electronic resource]. Available at: https://tass.ru/nedvizhimost/6945236 (Accessed: 05 October 2019) (in Russian).

[3] O. N. Kuzina, "Informacionnoe modelirovanie stoimosti ob"ekta stroitel'stva na kazhdom etape zhiznennogo cikla", Nauchnotekhnicheskij vestnik Povolzh'ya, 2019, no. 1, pp. 107-111 (in Russian).

[4] I. V. Laguta, G. G. Starygina, and A. O. Nesterova, "Ekonomicheskaya effektivnost' ot izmeneniya rascenok prianalize smetnoj dokumentacii", V sbornike: Problemy razvitiya sovremennogo obshchestva, Sbornik nauchnyh statej 4-j Vserossijsko jnauchno-prakticheskoj konferencii, YUgo-zapadnyj gosudarstvennyj universitet, 2019, pp. 151-153 (in Russian). 
Web of Conferences Ser. International Science Conference SPbWOSCE-2016 "SMART City", 2017, 08047 p.

[5] N. K. Samal', "Metodika opredeleniya stoimosti stroitel'stva: novye podhodyi effektivnost'", Trudy BGTU, seriya 5: Ekonomika I upravlenie, 2019, no. 1 (220), pp. 73-79 (in Russian).

[6] R. Hanov, "Informacionnoe obespechenie realizacii investicionnyh proektov", Innovacionnaya nauka, 2019, no. 2, pp. 102-107 (in Russian).

[7] O.V.SHnyrko, M. V. Ivashkina, and A. V. Kolesnikova, "Processyceno obrazovaniya v stroitel'stve v sovremennoj ekonomike", V sbornike: Sovremennye problemy ekonomicheskogo razvitiya predpriyatij, otraslej, kompleksov, territorij, Materialy Mezhdunarodnoj nauchnoprakticheskoj konferencii: v 2 tomah, 2019, pp. 41-45.

[8] L. Gerasimova and D. Silka, "Concept of costs management with environmental protection functions", International Science Conference SPbWOSCE-2018, Business Technologies for Sustainable Urban Development, E3S Web Conf. Volume 110, 2019.

[9] M. Panteleeva and S. Borozdina, "Programme planning methods for enterprise activities in the territorially concentrated construction complex", V sbornike: MATEC Web of Conferences 2018, 05006 p.

[10] M. Panteleeva and S. Borozdina, "Planning the amount of construction work by modelling the industry competitive field", V sbornike: MATEC
[11] V. Kankhva, "Using the entropy of cover method in the analysis of investment risks", MATEC Web of Conferences 212 (2): 08003, January 2018.

[12] M. I. Kamenetskii and N. Y. Yaskova, "Construction and real estate markets: from crisis to growth", Studies on Russian Economic Development, 2018, T. 29, no. 1, pp. 35-40.

[13] I. Lukmanova and N. Yaskova, "Mechanisms for accelerating the process of the infrastructure renewal", MATEC Web of Conferences 212, 2018, $09003 \mathrm{p}$.

[14] D. Silka, "Modern methods of cost saving of the production activity in construction", IOP Conference Series: Earth and Environmental Science 19, Ser. "Energy Management of Municipal Transportation Facilities and Transport, EMMFT 2017", 2017, 012155 p.

[15] N. Yaskova, "Strategic advantages of high-rise construction", V sbornike: E3S Web of Conferences Ser. "High-Rise Construction 2017, HRC 2017, 2018, 03025 p. 